\title{
Temperature Influence on Larval Growth and Metamorphosis of the Japanese Flounder Palalichthys olivaceus in the Laboratory
}

\author{
Tadahisa Seikai, ${ }^{* 1}$ Jean Beran Tanangonan, ${ }^{* 2}$ and Masaru Tanaka*2 \\ (Accepted November 21, 1985)
}

\begin{abstract}
The growth, development and metamorphosis of larval flounder Paralichthys olivaceus were examined at three temperatures of 13,16 and $19^{\circ} \mathrm{C}$ in the laboratory. Under conditions of sufficient food supplies and reasonable stocking densities, temperature markedly influenced the larval growth, development and metamorphosis. The larvae grew to $20 \mathrm{~mm}$ TL in 79,44 and 33 days after hatching, especially during postlarval stage with average growth rates of $0.22,0.43$ and $0.59 \mathrm{~mm} /$ day at 13,16 and $19^{\circ} \mathrm{C}$, respectively. The integrated water temperatures in which fish grew to $20 \mathrm{~mm}$ TL were approximated as being 970,700 and $620^{\circ} \mathrm{C}$ day at 13,16 and $19^{\circ} \mathrm{C}$, respectively. Larval development was also prominently influenced by temperature, the mean residence time at each developmental stage (ten stages from hatching to early juveniles) was estimated as being $3,4-5$ and 8-9 days at 19,16 and $13^{\circ} \mathrm{C}$, respectively. Fish sizes immediately after complete metamorphosis were found to be dependent on the ambient water temperature: the average body length at the last stage of metamorphosis was 11.0, 12.4 and $13.5 \mathrm{~mm} \mathrm{BL}$ (after fixation) at 19, 16 and $13^{\circ} \mathrm{C}$, respectively. It was speculated that, in higher temperatures, the development and metamorphosis of flounder larvae rather than growth were stimulated.
\end{abstract}

The Japanese flounder Paralichthys olivaceus is one of the most important commercial species among Japanese pleuronectiforms and widely distributed from Kyushu to Hokkaido, being particularly abundant in the Japan Sea. On the Wakasa Bay area, at the central part of the Japan Sea, its spawning season is known to be from March to May., ${ }^{1,2}$ During this period, water temperature increases from about 11 to $20^{\circ} \mathrm{C}{ }^{* 3}$ We can predict that larval growth will be slow in the early season and accelerate in the latter part of the season. However, we have no precise information about thermal effects on larval growth for the present species.

Water temperature has been shown to be one of the most important factors influencing growth and development of fish larvae in both laboratory ${ }^{3)}$ and wild environments. ${ }^{4}$ However, numerous works have considered thermal effects on embryonic development, few studies ${ }^{5,0}$ have been focussed on growth and development from hatching to metamorphosis. Many rearing experiments have been performed on the larvae and juveniles of $\boldsymbol{P}$. olivaceus mainly related to the mass production of seedling in Japan, but since these were done under uncontrolled water temperature, ${ }^{7-10)}$ thermal influences have remained nearly unsolved, even in the laboratory.

The objective of this study is to verify temperature influences upon the larval growth and development of the Japanese flounder $\boldsymbol{P}$. olivaceus from hatching through metamorphosis under laboratory conditions.

\section{Materials and Methods}

Flounder eggs, fertilized on April 13, 1983, were obtained from the Kyoto Prefectural Institute of Oceanic and Fishery Science, Miyazu, where laboratory-reared adult flounders spontaneously spawned in a tank every day from early April to late June. On April 14, eggs were transported to the Fisheries Research Station, Kyoto University and were incubated in a $500 l$ tank at $15^{\circ} \mathrm{C}$, this being concidered the optimum temperature for flounder embryos. Three groups of 1,500 eggs were transferred to 3 transparent polycarbonate tanks $(51 \mathrm{~cm}$ in diameter, $50 \mathrm{~cm}$ in depth and $100 l$ in volume) just before hatching. Immediately after hatching, tank temperatures

*1 Fisheries Research Station, Faculty of Agriculture, Kyoto University, Maizuru, Kyoto 625, Japan (青海 忠久: 京都大学農学部付属水座実験所).

*2 Department of Fisheries, Faculty of Agriculture, Kyoto University, Kitashirakawa, Kyoto 606, Japan (タナンゴナン・ジン・ベン，田中 克：京都大学紫学部水産学科).

*3 Kyoto Pref. Fish. Exp. St.: Annual Rep. Kyoto Pref. Fish. Exp. St. in 1976, 1-17 (1978). 
were gradually adjusted to either 13,16 or $19^{\circ} \mathrm{C}$ using heating and cooling coils. Three temperatures were selected for the experiment because they correspond to the natural temperature range of spawning and occurrence of early larvae in the Wakasa Bay area. ${ }^{1,2)}$ Mean temperature in each tank was maintained at $12.58 \pm 0.38,15.69 \pm 0.68$, and $19.07 \pm 0.48^{\circ} \mathrm{C}$, respectively. Integrated water temperatures during experiments were cal- culated as the sum of daily temperature measured at 9 a.m..

Water in the rearing tanks was aerated with air stones at a rate of $50-100 \mathrm{ml} / \mathrm{min}$. and changed continuously at a rate of 3 turnovers/day. Controlled illumination with fluorescent lamps gave a 13:11 light-dark photoperiod with light intensities being maintained at $1,000 \mathrm{~lx}$ at each tank surface. Larvae were fed L-type rotifers Brachionus

Table 1. Morphological characters for classification of developmental stages during the larval and early juvenile periods of flounder

\begin{tabular}{lll}
\hline Developmental stages & \multicolumn{1}{c}{ Main characters at each stage } \\
\hline Prelarval period: & PL & Yolk sac larvae \\
Postlarval period: & A & Opening of mouth \\
& Gut with single loop \\
& B & Bud of elongate anterior dorsal fin rays \\
& C & 3 elongate anterior dorsal fin rays \\
& Bud of caudal fin rays \\
& Beginning of body compression \\
& 5 elongate anterior dorsal fin rays \\
& 6 caudal fin rays \\
& Notchord flexed upward (45) \\
& Bud of dorsal and anal fin rays \\
& Beginning of eye migration \\
& F elongate anterior dorsal fin rays \\
& Proliferation of dorsal and anal fin rays \\
& Right eye unobservable from left side \\
& Right eye observable from left side \\
& Right eye migration on the dorsal edge or the head \\
& Completion of metamorphosis (eye migration, atrophy of \\
& I & Full adult complement of rays \\
\hline
\end{tabular}

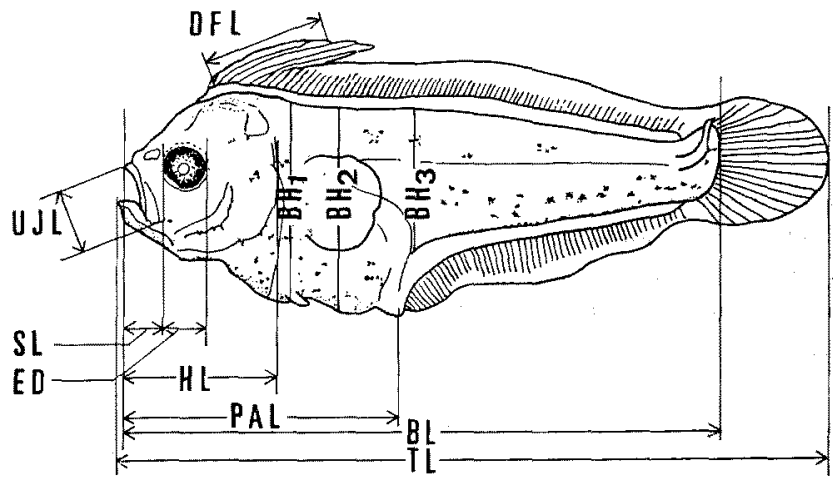

Fig. 1. Body parts of flounder larvae and juveniles measured in this study.

$\mathrm{TL}$, total length (straight-line distance from anterior-most part of head to tip of tail); $\mathrm{BL}$, body length (straight-line distance from tip of snout to either posterior tip of notchord or end of hypural); PAL, pre-anal length; HL, head length; SL, snout length; ED, horizontal eye diameter; UJL, upper jaw length; DFL, 3rd dorsal fin ray length; $\mathrm{BH}$, body height at pectral fin origin; $\mathrm{BH} 2$, maximum body height excluding muscles of dorsal fin; $\mathrm{BH} 3$, body height at posterior part of anal excluding muscles of dorsal and anal fins. 
plicatilis and newly hatched brine shrimp Artemia nauplii. Rotifers, being cultured with Chlorella sp. and baker's yeast, were introduced to the experimental tanks after enrichment with sufficient Chlorella sp. for 12 hours or more. Cysts of brine shrimp were Tien-tsin, China 1982 strain. To allow fishes to take sufficient food, they were maintained under an excess food supply throught the experimental period.

Ten to thirty larvae or juveniles were sampled from each tank every day during the prelarval period and every 5 days during the postlarval period. Total length (TL) of each specimen was measured after anaestetizing with MS-222 (about $20 \mathrm{ppm}$ in sea water), and each specimen was preserved in $5 \%$ neutralized formalin for later analysis. Further detailed measurements were made after four months from sampling, this being regarded as sufficient time for complete shrinkage in formalin*. For analysis of size-development relationships, all specimens were classified into one of 10 developmental stages; one for the prelarval period (PL stage), eight for the postlarval period (A to $\mathrm{H}$ stage), and one for the juvenile period (I stage) (Table 1). The developmental stages A to I established for wild flounders ${ }^{2)}$ were applied to the present laboratory flounders. Measurements were also made on 11 body parts of all specimens as shown in Fig. 1. Relative growth was examined in terms of the ratio of each part to the body length at 13 and $19^{\circ} \mathrm{C}$.

\section{Results}

\section{Growth}

The growth curves at three different temperatures are shown in Fig. 2. Although mean larval sizes in the three experimental tanks were nearly the same on one day after hatching (about 3.6$3.7 \mathrm{~mm}$ TL), they became markedly varied with an increase in days. On the 30th day, all fishes at $19^{\circ} \mathrm{C}$ had completely metamorphosed into juveniles measuring $19.4 \mathrm{~mm}$ TL, while fishes at $13^{\circ} \mathrm{C}$ had not yet metamorphosed, measureing only about $8.6 \mathrm{~mm} \mathrm{TL}$. At $16^{\circ} \mathrm{C}$, mean length was about $13.9 \mathrm{~mm} \mathrm{TL}$, and some fishes had metamorphosed into juveniles. The size at which most larvae metamorphosed into juveniles was found to be $15 \mathrm{~mm} \mathrm{TL}$, and was attained at about 24,32 and 55 days after hatching at 19,16 and $13^{\circ} \mathrm{C}$, respectively. The average daily growth rate in terms of length throughout the postlarval

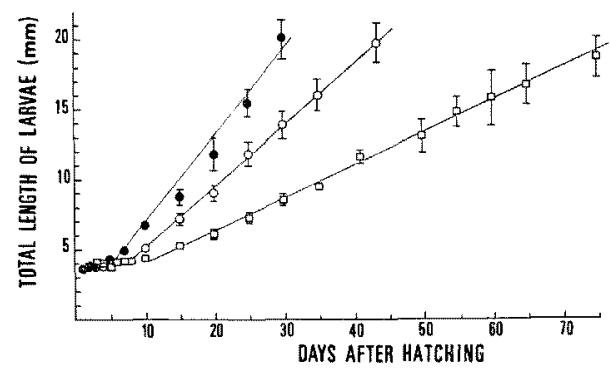

Fig. 2. Growth of flounder larvae and early juveniles. Open squares, open circles and closed circles show mean total length of larvae reared at 13,16 and $19^{\circ} \mathrm{C}$, respectively. The vertical lines indicate one unit of standard deviation of total length. The equation of the relationship between days after hatching $(X)$ and TL $(Y, 4<Y<$ $20 \mathrm{~mm})$ is $Y=2.2194+0.2237 X \quad(r=0.9969)$, $Y=1.2013+0.4295 X(r=0.9939)$ and $Y=0.7278$ $+0.5895 X(r=0.9853)$ at 13,16 , and $19^{\circ} \mathrm{C}$, respectively.

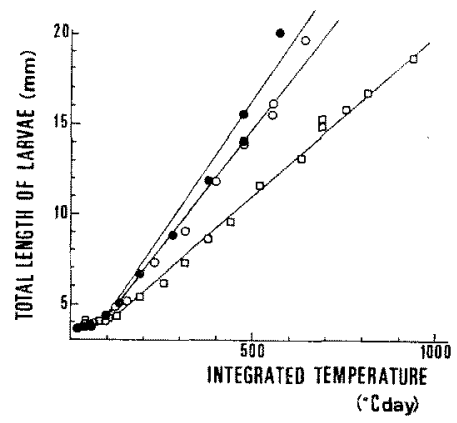

Fig. 3. The relationship between total length and integrated water temperature for flounder larvae. Open squares, open circles and closed circles show the values at 13,16 and $19^{\circ} \mathrm{C}$, respectively. The equation of the relationship between integrated temperature $(X)$ and TL $(Y, 4<Y<20$ $\mathrm{mm})$ is $Y=2.1961+1.7779 \times 10^{-2} X(r=0.9973)$, $Y=1.3331+2.6799 \times 10^{-2} X(r=0.9954)$ and $Y=$ $0.8601+3.0789 \times 10^{-2} X(r=0.9864)$ at 13,16 and $19^{\circ} \mathrm{C}$, respectively.

period was estimated at $0.22,0.43$ and $0.59 \mathrm{~mm} / \mathrm{day}$ at 13,16 and $19^{\circ} \mathrm{C}$, respectively.

Although water temperature greatly influenced larval growth, the degree of influence was not necessarily the same at all experimental temperatures. The relationship between larval length (TL) and integrated water temperature differed among experimental tanks, those at 16 and $19^{\circ} \mathrm{C}$ being nearly the same, while that at $13^{\circ} \mathrm{C}$ differed

\footnotetext{
* unpublished data.
} 
significantly from the others (Fig. 3). The integrated water temperatures at which fish reached $20 \mathrm{~mm}$ TL were calculated as being about 970 , 700 and $620^{\circ} \mathrm{C}$ day at 13,16 and $19^{\circ} \mathrm{C}$, respectively.

\section{Development and Metamorphosis}

Like most marine fishes having isolated pelagic eggs, flounder larvae hatch out with the major organs in an altricial state. Major morphorogical and ecological changes occur during the prelarval period. Such developmental events as mouth opening, eye pigmentation, first feeding and yolk absorption, were greatly affected by incubation temperature, as shown in Table 2. The duration requirements for each event were approximatedly 2.3 to 3.0 times greater at $13^{\circ} \mathrm{C}$ than at $19^{\circ} \mathrm{C}$.

The relationship between advances in the developmental stages and days after hatching is shown in Fig. 4. The time larvae spent from hatching through metamorphosis (I stage) averaged 27,38 and 70 days at 13,16 and $19^{\circ} \mathrm{C}$, respec-

Table 2. The time from hatching, when each developmental event occurrs during prelarval period of flounder at three temperatures

\begin{tabular}{lccc}
\hline \multirow{2}{*}{ Events } & \multicolumn{3}{c}{$\begin{array}{l}\text { Duration of events } \\
\text { (days after hatching) }\end{array}$} \\
\cline { 2 - 4 } & $13^{\circ} \mathrm{C}$ & $16^{\circ} \mathrm{C}$ & $19^{\circ} \mathrm{C}$ \\
\hline Mouth opening & $(6)$ & $(4)$ & $(2)$ \\
Eye pigmentation & $(6)$ & $(4)$ & $(2)$ \\
First feeding & $(7)$ & $(5)$ & $(3)$ \\
Yolk absorption & $(8)$ & $(5)$ & $(3)$ \\
\hline
\end{tabular}

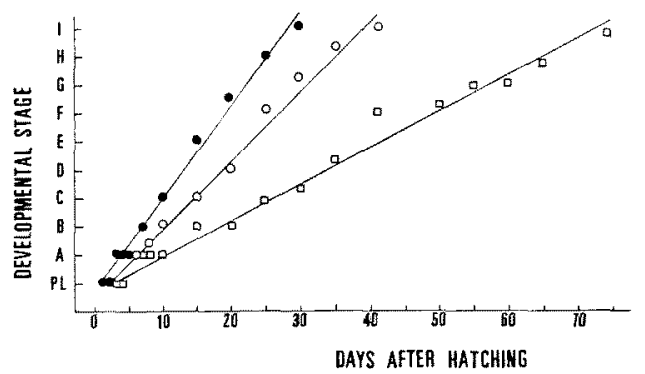

Fig. 4. Age-developmental stage relationship of flounder larvae.

Open squares, open circles and closed circles show the values at 13,16 and $19^{\circ} \mathrm{C}$, respectively. The equation of relationship between days after hatching $(X)$ and developmental stage $(Y)$ is $Y=1.0510+0.1183 X \quad(r=0.9838), \quad Y=0.8838+$ $0.2171 X \quad(r=0.9790)$ and $Y=0.8128+0.3068 X$ $(r=0.9837)$ at 13,16 and $19^{\circ} \mathrm{C}$, respectively.

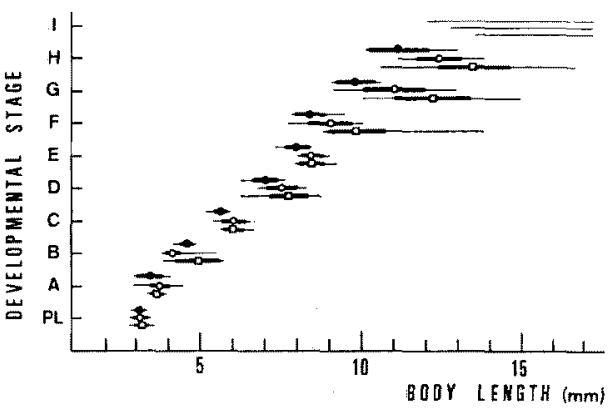

Fig. 5. Size distribution at each developmental stage of flounder larvae.

Open squares, open circles and closed circles show mean body length at each developmental stage of specimens reared at 13,16 and $19^{\circ} \mathrm{C}$, respectively. The horizontal thick lines (thin lines) show one unit of standard deviation (ranges) of body length.

tively. Since a linear relationship was observed at each temperature, the residence time at each developmental stage was estimated as being 3 days, 4-5 days and 8-9 days at 19,16 and $13^{\circ} \mathrm{C}$, respectively.

Fig. 5 illustrates the size distribution, showing the mean, standard deviation and range at each stage. At earlier stages (PL to $C$ stage), larval sizes did not differ greatly among the three rearing temperatures. Although the variation in meansize among all three temperatures increased with the advance in the development during the later stages, it was noticeably larger at lower temperatures. In respect to the developmental stage, markedly greater size differences were observed at stage $F, G$ and $H$, corresponding to the early, middle and late phases of metamorphosis. Thus, fish sizes were found to be dependent on the ambient water temperature: the average body length at the last stage of metamorphosis (stage H) was $11.0,12.4$ and $13.5 \mathrm{~mm}$ at 19,16 and $13^{\circ} \mathrm{C}$, respectively. The size range of a single stage increased markedly during metamorphosis stages $\mathrm{F}$ to $\mathrm{H}$, being most prominent at $13^{\circ} \mathrm{C}$, when size ranged from a minimum of $10.6 \mathrm{~mm} \mathrm{BL}$ to a maximum of $16.7 \mathrm{~mm} \mathrm{BL}$ in stage $\mathrm{H}$.

Fig. 6 shows the relative growth of 10 body parts, shown as a percentage of each body part to the body length; total length (TL), pre-anal length (PAL), head length (HL), upper jaw length (UJL), snout length (SL), elongate dorsal fin ray length (DFL) and 3 types of body height $\left(\mathrm{BH}_{1-3}\right)$. Flection points varied slightly with body parts, but major 
points common to every part were observed at about $10 \mathrm{~mm}$ BL. As with the mean size of each stage, the size of the points at $13^{\circ} \mathrm{C}$ were found to be discernibly larger than those at $19^{\circ} \mathrm{C}$. Furthermore, the percentage of each body part to $\mathrm{BL}$ were also found to be higher at $19^{\circ} \mathrm{C}$ than at $13^{\circ} \mathrm{C}$ in PAL/BL and three types of $\mathrm{BH} / \mathrm{BL}$. These differences found in the body proportions between temperatures imply a more slender body form at $13^{\circ} \mathrm{C}$.

\section{Discussion}

In the present experiment, the flounders were initially maintained at a density $15 \mathrm{eggs} / l$. Because of failure in embryonic development, stock-
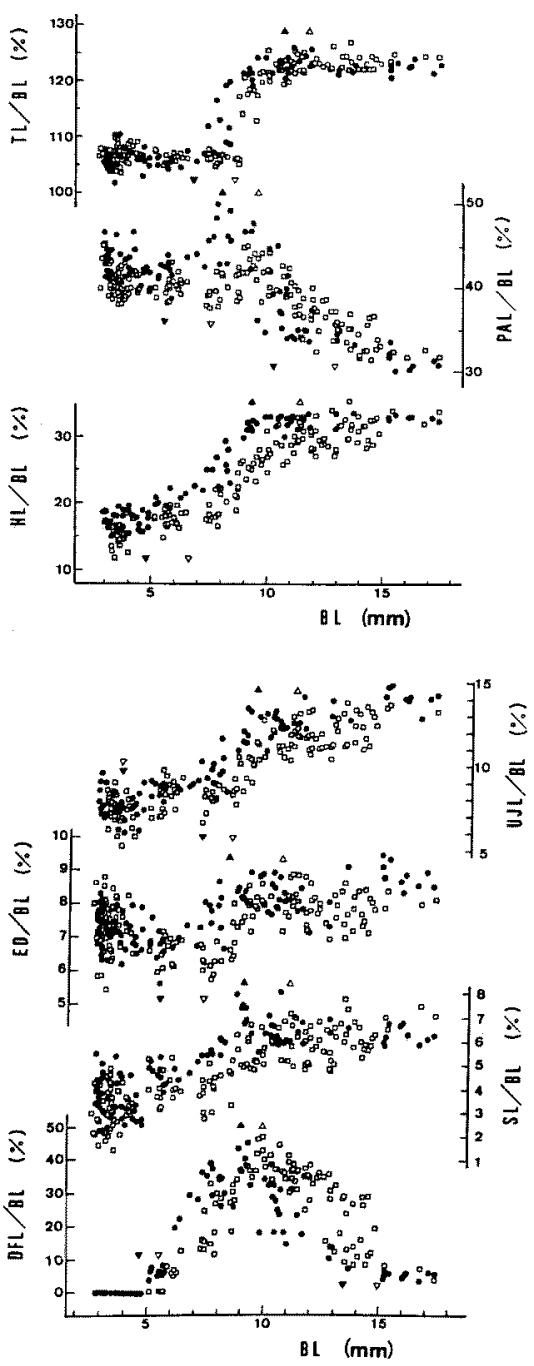

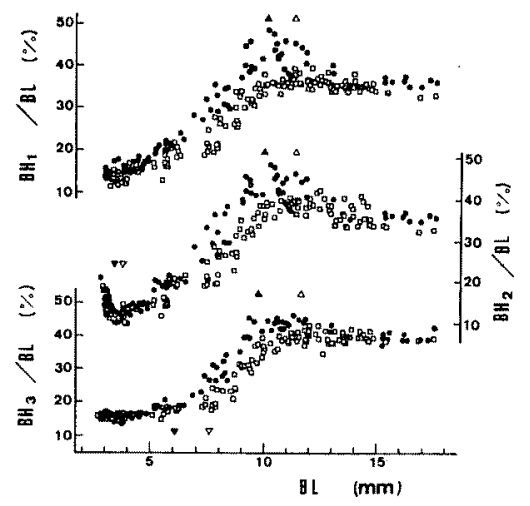

Fig. 6-1 3. Relative growth of flounder larvae: parcent of body parts to body length.

Number of specimens used was 220 (111) larvae reared at $13^{\circ} \mathrm{C}\left(19^{\circ} \mathrm{C}\right)$. Open squares (closed circles) show the relative growth (\%) of 10 body parts to $\mathrm{BL}$ of larvae reared at $13^{\circ} \mathrm{C}\left(19^{\circ} \mathrm{C}\right)$. Open triangles (closed triangles) show the flection points for the relative growth curves of 10 body parts to $\mathrm{BL}$ at $13^{\circ} \mathrm{C}\left(19^{\circ} \mathrm{C}\right)$.

ing densities were finally adjusted to about 10 fishes/l several days after hatching. This density is not excessive when compared with other experiments for flounder larvae. ${ }^{8,10)}$ It is well known that larval growth is suppressed in high densities such as 16 or 32 larvae/l under limited food supplies. ${ }^{11}$ The quality and quantity of supplied foods were always sufficient in the present experiment. It is interesting to note that the growth rates of larvae were higher at 19 and $16^{\circ} \mathrm{C}$, in which real stocking densities were higher than that at $13^{\circ} \mathrm{C}$. It is therefore reasonable to consider that stocking density was an insignificant factor affecting the growth of flounders in the present experiment and we can safely assume that water temperature was the major factor influencing larval growth under conditions of sufficient food supplies and reasonable stocking densities. The rates obtained here were high compared with those carried out in nearly equivalent thermal conditions $^{10)}$ and may thus be regarded as being near maximum under the laboratory conditions.

Larval growth was found to be markedly suppressed at $13^{\circ} \mathrm{C}$, as was clearly shown by the larger relative integrated temperature value. In the Wakasa Bay area, early flounder larvae begin to appear at water temperatures of about $\left.13^{\circ} \mathrm{C},{ }^{1}\right)$ but experience increasing thermal environments with growth. Although the minimum temperature at which larvae could grow was not confirmed, 
$13^{\circ} \mathrm{C}$ may be regarded as being near the biological zero $^{12)}$ for the flounder larvae. Most fishes develop from larvae, whose morphological features are appreciably different from adults, to juveniles of adult-like features through metamorphosis. ${ }^{12}$ ) In particular, pleuronectiforms undergo a typical metamorphosis during which an eye migrates from one side of the body to the other. Fish metamorphosis seems to be affected by many external and internal factors, but little is known in this respect. In the starry flounder Platichthys stellatus metamorphosis was mainly dependent not on age but on larval size, and the metamorphic size was little affected by temperature. ${ }^{\text {. }}$ Although the metamorphosis of $P$. olivaceus was not dependent on age, unlike the starry flounder, the metamorphic size was markedly influenced by ambient temperature.

Amphibian metamorphosis, directly controlled by thyroid hormones, ${ }^{13}$ ) is largely dependent on ambient temperature. ${ }^{14)}$ Scince lower temperatures inhibit the activity of thyroid hormones and tissue susceptibility to the hormones, metamorphosis is markedly suppressed, resulting in prolonged premetamorphic duration and larger metamorphic size. ${ }^{14,10)}$ Conversely, at higher temperatures, metamorphosis, rather than growth, is accelerated, resulting in a shorter larval period and smaller metamorphic size. These tendencies verified in amphibian metamorphosis closely resemble that of the flounder, and we can assume that a similar mechanism may occur here. Further studies from both an endocrinological and histological viewpoint are needed to examine such hormone-controlled metamorphosis.

We consider that the most interesting result obtained in this experiment is the temperaturedependence of metamorphic size and duration of larval period. Such experimental information is surely of importance in analysing the events during the early life history of fishes in the sea; larval transport from the spawning grounds, survival during pelagic life, and inshore migration to the nursery grounds. We greatly need to asses the adaptive significance of metamorphic variability, combining laboratory and field data.

In the present study, larval growth was examined only in terms of length. Further detailed analyses should be done on a dry weight baisis and monitored the daily food ration and oxygen consumption. ${ }^{18,17)}$

\section{Acknowledgements}

We are very grateful to Dr. I. Nakamura, Kyoto University Fisheries Research Station, Dr. A. Tandler, National Center for Mariculture Israel Oceanographic \& Limnological Research, Mr. G. Minkoff, Scotish Marine Research Laboratory for usefull suggestions or critical reading of the manuscript. We also thank Mr. M. Shimozaki, Tokyo University of Fisheries for technical assistance of rearing experiments.

\section{References}

1) T. Minami: Bull. Japan. Soc. Sci. Fish., 48, 1581-1588 (1982).

2) A. Kuwahara and S. Suzuki: Bull. Japan. Soc. Sci, Fish., 48, 1375-1381 (1982).

3) D. Kramer and J.R. Zweifel: Calif. Coop. Ocean. Fish. Inv., Rep., 14, 84-87 (1970).

4) R. D. Methot Jr. and D. Kramer: Fish. Bull., U.S., 77 (2), 413-423 (1979).

5) G. C. Laurence: Mar. Biol., 32, 223-229 (1975),

6) D. Policansky: Can, J. Fish. Aquat. Sci., 39, 514-517 (1982).

7) T. Harada, S. Uumeda, O. Murata, H. Kumai, and K. Mizuno: Bull. Fish. Lab. Kinki Univ., 1, 289-303 (1966).

8) T. Midorikawa: Saibai Giken, 3 (1), 15-21 (1974).

9) Y. Hiramoto and K. Kobayashi: Saibai Giken, 8 (1), 41-51 (1979).

10) Y. Hiramoto, K. Kobayashi, and N. Miki: The Aquiculture, 28 (3), 134-141 (1980).

11) E. D. Houde: J. Fish Biol., 7, 115-127 (1975).

12) J. H. S. Blaxter: in "Fish phisiology" (ed. by W. S. Hoar and D. J. Randall), Vol. III, Academic press, New York and London, 1969, pp. 178-241.

13) J. F. Gundernatsch: Wilhelm Roux Arch. Entwichlungsmech. Organismen, 35, 457-483 (1912).

14) W. Etkin: in "Analysis of development" (ed. by B. H. Willier, P. A. Weiss, and V. Hamburger), W. B. Saunders Co., Philadelphia, 1955, pp. 631663.

15) J. J. Kollros: Amer. Zool., 1, 107-114 (1961).

16) G. C. Laurence: Fish. Bull. U.S., $75(3), 529-$ 546 (1977).

17) G. C. Laurence: Mar. Biol., 50, 1-7 (1978). 